\title{
ISOLASI DAN KARAKTERISASI BAKTERIOFAG SPESIFIK SALMONELLA TYPHI DARI KULIT AYAM
}

\author{
Isolation and Identification of Salmonella typhi Bacteriophage Specific \\ from Chicken Skin
}

\author{
Sri Hardanti*, Agustin Krisna Wardani*, Widya Dwi Rukmi Putri \\ Jurusan Teknologi Hasil Pertanian - Fakultas Teknologi Pertanian - Universitas Brawijaya \\ Jl. Veteran Malang 65145 \\ *Penulis Korespondensi: email: ciciseuri@yahoo.com; wardani8@yahoo.com
}

\begin{abstract}
ABSTRAK
Salmonella enterica serovar Typhi merupakan bakteri gram negatif yang menyebabkan demam tifoid sangat endemik di Indonesia. Penggunaan antibiotik yang tidak terkontrol menimbulkan kasus resistensi yang menyebabkan tidak efektifnya pengobatan. Hal ini membutuhkan alternatif penanganan yang lebih efektif, efisien, ramah lingkungan dan aman. Tujuan penelitian ini adalah mendapatkan bakteriofag spesifik Salmonella typhi dari sampel kulit ayam broiler dan mengarakterisasi fag yang dihasilkan secara morfologi. Pelaksanaan penelitian meliputi proses pengayaan dan isolasi bakteriofag dari sampel kulit ayam broiler menggunakan metode plaque assay dengan teknik agar overlay, dilanjutkan dengan uji konfirmasi bakteriofag secara in vitro menggunakan spektrofotometer dan uji karakterisasi morfologi terhadap fag yang dihasilkan menggunakan Transmission Electron Microscopy (TEM). Isolasi bakteriofag dari kulit ayam broiler berhasil mengisolasi fag spesifik Salmonella typhi yang diberi nama KAS dengan konsentrasi akhir $1.1 \times 10^{9} \mathrm{PFU} / \mathrm{ml}$. Berdasarkan hasil pengamatan terhadap plaque yang terbentuk, fag KAS (Kulit ayam-Salmonella typhi) dikategorikan sebagai fag litik. Hasil uji konfirmasi fag KAS dalam medium cair menunjukan bahwa fag KAS memiliki kemampuan bervariasi dalam menurunkan jumlah bakteri patogen Salmonella typhi dengan nilai MOI 1010 102, dan 104. Hasil Transmission Electron Microscopy (TEM) menunjukan bahwa fag KAS memiliki karakteristik morfologi yang mirip dengan famili Podoviridae
\end{abstract}

Kata kunci : Bakteriofag, Isolasi, Kulit Ayam, Salmonella typhi

\begin{abstract}
Salmonella enterica serovar Typhi is a gram-negative bacteria that causes typhoid fever endemic in Indonesia. The use of uncontrolled antibiotics leads to resistance cases that result to ineffective treatment. This problems are requiring more effective, efficient, environmentally friendly and safe handling alternatives. The aim of this research is to get bacteriophage specific Salmonella typhi from chicken skin sample and characterize phage produced morphologically. The research implementation includes enrichment process and bacteriophage isolation from broiler chicken using plaque assay method with overlay technique, followed by bacteriophage confirmation test in vitro using spectrophotometer and phage morphology characterization test using Transmission Electron Microscopy (TEM). Isolation of bacteriophage has succeeded in isolating phage specific Salmonella typhi named KAS (Chicken Skin-Salmonella typhi) with final concentration of $1.1 \times 10^{9} \mathrm{PFU} / \mathrm{ml}$. Based on the observation of the plaque formed, the KAS phage is categorized as litic phage. The results of the confirmation test of phage KAS in liquid medium showed that phage KAS has varied ability in decreasing number of pathogenic bacteria Salmonella typhi with MOI value $10^{1}, 10^{2}$, and $10^{4}$. Transmission Electron Microscopy (TEM) revealed phage KAS has morphological characteristics similar to Podoviridae
\end{abstract}

Keywords : Bacteriophage, Chicken Skin, Isolation, Salmonella typhi, 


\section{PENDAHULUAN}

Demam tifoid adalah salah satu masalah kesehatan masyarakat di negara berkembang yang disebabkan oleh patogen Salmonella enterica serotype Typhi (Salmonella typhi) yang seringkali mengancam jiwa di seluruh dunia (Ochiai et al., 2008; Alba et al., 2016). Data perkiraan terakhir pada tahun 2010 melaporkan telah terjadi 13.5 juta penyakit di seluruh dunia dengan tingkat kejadian tertinggi terjadi di Asia dan Afrika (Buckle et al., 2012; Crump et al., 2004). Indonesia merupakan salah satu negara endemik demam tifoid dengan tingkat kematian paling tinggi bersama New Guinea di Asia Tenggara (Crump et al., 2004). Berdasarkan penelitian Ochiai et al. (2008) yang dilakukan di Jakarta melaporkan telah terjadi 148.7 kasus demam tifoid per 100000 orang per tahun pada kelompok umur 2-4 tahun, 180.3 kasus demam tifoid per 100000 orang per tahun pada kelompok umur 5-15 tahun, dan 51.2 kasus demam tifoid per 100000 orang per tahun pada kelompok umur lebih dari 16 tahun dengan tingkat kematian mencapai 10$30 \%$ (tanpa penanganan efektif) dan menurun menjadi $1-4 \%$ (dengan penanganan yang tepat). Penggunaan antibiotik yang dilakukan untuk mengatasai masalah demam tifoid menimbulkan masalah lain berupa resistensi. Hatta dan Ratnawati (2008) melaporkan bahwa dalam rentang tahun 2001-2007 telah terjadi trend peningkatan resistensi terhadap beberapa antibiotik yang digunakan untuk mengobati demam tifoid di Indonesia seperti ampicillin, chloramphenicol, co-trimoxazole dan ciprofloxacin. Hal ini diperkirakan akan menjadi masalah serius di masa depan sehingga diperlukan suatu cara yang efektif, efisien, ramah lingkungan serta aman untuk menangani kasus demam tifoid yang disebabkan oleh Salmonella typhi.

Bakteriofag merupakan virus yang menyerang bakteri. Bakteriofag merupakan salah satu alternatif untuk mengatasi masalah infeksi bakteri patogen. Penggunaan bakteriofag dipertimbangkan lebih menguntungkan dibandingkan antibiotik. Bakteriofag hanya menginfeksi patogen target, sehingga mikroflora normal di usus tidak terganggu, kedua bakteriofag mereplikasi diri pada bakteri dan menghancurkan sel bakteri inang dengan sempurna melalui proses lisis membunuh bakteri yang menjadi inangnnya (Strydom dan Witthuhn, 2015; Connerton dan Connerton, 2005).
Keberadaan bakteriofag tersebar luas di alam. Lingkungan yang ditempati oleh bakteri inang merupakan sumber keberadaan berbagai jenis fag yang dapat diisolasi untuk berbagai tujuan (Shende et al., 2017). Meskipun demikian jumlah bakteriofag yang sudah teridentifikasi di dunia masih terbatas (Casjens, 2008), sehingga penelitian terkait isolasi dan identifikasi bakteriofag terus dilaksanakan di berbagai negara di dunia. Kelimpahannya yang sangat tinggi di alam (Pedulla et al., 2003), keberadaannya sebagai mikroflora alami pada makanan (Atterbury et al., 2006), kemampuan untuk menginfeksi dan membunuh sel bakteri inang melalui proses lisis (Rao, 2006; Susianto et al., 2014; Cheng et al., 2018; Harada et al., 2018), dan spesifitas dalam menyerang inang target (Donnison dan Ross, 2014; Kittler et al., 2017; Harada et al., 2018; Santos et al., 2018) merupakan potensi yang menjanjikan untuk menjadikan bakteriofag sebagai biokontrol terhadap bakteri patogen khususnya Salmonella typhi. Pada penelitian ini dilakukan isolasi dan identifikasi bakteriofag dari sampel kulit ayam broiler untuk memperoleh agen potensial yang dapat digunakan untuk mengendalikan bakteri patogen penyebab demam tifoid yang mengalami multidrug resistant (MDR).

\section{BAHAN DAN METODE}

\section{Bahan}

Bakteri uji Salmonella typhi diperoleh dari Laboratorium Mikrobiologi Fakultas Kedokteran Universitas Brawijaya, MalangJawa Timur. Sampel kulit ayam broiler betina sebagai sumber bakteriofag diperoleh dari pasar tradisional di kota Malang-Jawa Timur. Medium yang digunakan untuk pertumbuhan Salmonella typhi yaitu broth (NB) yang mengandung $15 \mathrm{~g} / \mathrm{L}$ pepton, $3 \mathrm{~g} / \mathrm{L}$ yeast extract, dan $6 \mathrm{~g} / \mathrm{L} \mathrm{NaCl}$, dan nutrient agar (NA) yang mengandung $5 \mathrm{~g} / \mathrm{L}$ pepton, $1 \mathrm{~g} / \mathrm{L}$ beef extract, $2 \mathrm{~g} / \mathrm{L}$ yeast extract, $15 \mathrm{~g} / \mathrm{L}$ agar dan $5 \mathrm{~g} / \mathrm{L} \mathrm{NaCl}$. Medium yang digunakan untuk isolasi dan pengujian bakteriofag adalah hard phage agar (NA dengan 1.5\% [w/v] agar) dan soft phage agar (NA dengan $0.6 \%$ [w/v] agar). Semua medium masing-masing ditambahkan $10 \mathrm{mM} \mathrm{CaCl}_{2}$ per liter media untuk menambah jumlah fag yang terbentuk (Loess- 
ner dan Busse, 1990). Cairan yang digunakan untuk dilusi (pengencer) kultur bakteri antara lain $0.1 \%$ pepton water $(\mathrm{PW}, 5 \mathrm{~g} / \mathrm{L}, \mathrm{NaCl}$ dan $10 \mathrm{~g} / \mathrm{L}$ pepton), sedangkan dalam isolasi fag digunakan Sodium-Magnesium buffer (SM buffer) (0.05 M-Tris KHl [pH 7.5]; 0.1 $\mathrm{M} \mathrm{NaCl} ; 0.008 \mathrm{M} \mathrm{MgSO}_{4} \times 7 \mathrm{H}_{2} \mathrm{O}$ dan $0.01 \%$ $(\mathrm{w} / \mathrm{v})$ gelatin).

\section{Alat \\ Alat yang digunakan dalam penelitian ini antara lain autoclave (Model HL-36 AE, Hirayama, Jepang, Inkubator (Binder BD 53 Germany), vortex (Turbo Mixer model LW Scientific), timbangan analitik (Mettler To- ledo AL 204), gelas beaker $250 \mathrm{ml}$, Erlenmeyer $250 \mathrm{ml}$, gelas arloji, spatula, kompor listrik (Maspion S-300 220V), mikropipet non-fixed $1000 \mu \mathrm{l}$ dan 40-200 $\mu \mathrm{l}$ (Finnipipett, lab sys- tem), sentrifuse dingin (Hettrich Zentrifugen Jerman), kulkas (Ruey Shing), mikropore ukuran $0.22 \mu \mathrm{m}$ (Sartorius).}

\section{Metode}

\section{Persiapan Kultur Bakteri Inang}

Kultur Salmonella typhi yang digunakan dalam penelitian ini disimpan dalam 20 $\%$ (v/v) gliserol pada suhu $-20{ }^{\circ} \mathrm{C} .100 \mu \mathrm{L}$ kultur beku diinokulasikan ke dalam $\mathrm{Nu}$ trien Broth (NB) dan diinkubasi semalam (1820 jam) pada suhu $37^{\circ} \mathrm{C}$ dengan kecepatan shaker $100 \mathrm{rpm}$. Kultur selanjutnya di gores menggunakan ose ke atas agar miring yang dibuat dari Nutrien Agar (NA), selanjutnya diberi segel dan disimpan pada suhu $4{ }^{\circ} \mathrm{C}$ sebagai persediaan sampai digunakan untuk keperluan selanjutnya. Ketika diperlukan, satu ose kultur dari agar miring dipindahkan ke atas permukaan NA diinkubasi pada suhu $37^{\circ} \mathrm{C}$ semalam (18-20 jam), selanjutnya koloni tunggal yang terbentuk dipindahkan ke dalam NB diinkubasi pada suhu $37^{\circ} \mathrm{C}$ di shaker dengan kecepatan 100 rpm sampai mencapai fase pertengahan log (midlog) untuk digunakan pada saat pengkayaan dan isolasi bakteriofag. Waktu pencapaian fase midlog bakteri inang ditentukan menggunakan spektrofotometer dengan panjang gelombang $600 \mathrm{~nm}$ (Optical Density $\left.=\mathrm{OD}_{600}\right)$. Selanjutnya nilai $\mathrm{OD}_{600}$ dibandingkan dengan jumlah sel $(\mathrm{CFU} / \mathrm{mL})$ dengan metode Total Plate Count (TPC).

\section{Persiapan Sampel}

Sampel kulit ayam ditimbang secara aseptik sebanyak $10 \mathrm{~g}$, kemudian dimasukan ke dalam kantung plastik steril dan ditambahkan $90 \mathrm{ml}$ air pepton $0.1 \%$. Selanjutnya dihomogenkan menggunakan stomacher selama 3 menit sampai terbentuk suspensi sampel, selanjutnya dimasukan ke dalam falcon steril yang berpenutup.

\section{Pengayaan Sampel}

Pengayaan sampel kulit ayam dilakukan berdasarkan metode Atterburry et al. (2003) dengan modifikasi. $1 \mathrm{~g}$ suspensi sampel kulit ayam diencerkan dalam SM buffer (50 mM Tris- $\mathrm{HCl}$ [pH [7.5], $0.1 \mathrm{M}$ $\mathrm{NaCl}, 8 \mathrm{mM} \mathrm{MgSO}{ }_{4} .7 \mathrm{H}_{2} \mathrm{O}, 0.001 \%$ gelatin] dengan perbandingan 1:10 kemudian di vortex selama 5 menit. Suspensi yang terbentuk selanjutnya diinkubasi selama 24 jam pada suhu $4{ }^{\circ} \mathrm{C}$ untuk membiarkan fag terelusi ke dalam buffer, selanjutnya $1 \mathrm{ml}$ aliquot disentrifugasi dengan kecepatan 10000 x g selama 3 menit untuk menghilangkan sel debris, supernatan yang terbentuk kemudian disaring menggunakan micropore ukuran $0.22 \mu \mathrm{m}$.

\section{Isolasi Bakteriofag}

Isolasi bakteriofag dilaksanakan berdasarkan metode Jamalludeen et al. (2007) dengan beberapa modifikasi. $100 \mu \mathrm{l}$ filtrat sampel hasil dari masing-masing metode pengayaan diencerkan dalam SM buffer (10 1 sampai 10-5). $100 \mu \mathrm{l}$ hasil pengenceran diambil dari setiap tabung kemudian dicampur dengan $100 \mu \mathrm{l}$ masing-masing kultur broth bakteri inang dalam tabung reaksi yang telah ditambahkan $\mathrm{CaCl}_{2}$ hingga mencapai konsentrasi akhir $10 \mathrm{mM}$ (Kang et al., 2013; Yang et al., 2010) kemudian diinkubasi pada suhu $37{ }^{\circ} \mathrm{C}$ selama 20 menit, selanjutnya ditambahkan $4 \mathrm{ml}$ soft phage agar dengan suhu 47 ${ }^{\circ} \mathrm{C}$. Tabung reaksi digoyangkan untuk mencampur semua yang terkandung didalamnya dan dituangkan ke atas cawan petri yang sudah mengandung hard phage agar dan dibiarkan memadat. Diinkubasi semalam (18-20 jam) pada suhu $37^{\circ} \mathrm{C}$. Hari berikutnya dilakukan pengamatan terhadap keberadaan plak dari bakteriofag. Tabung reaksi kontrol yang mengandung bakteri dan soft phage agar tanpa filtrat diinokulasi di atas hard phage agar pada cawan petri.

Plaque yang terbentuk pada cawan phage agar dihisap secara lembut menggunakan pipet pasteur bersama dengan agar yang mendasarinya. Isi pipet dipindahkan ke dalam $1 \mathrm{ml} \mathrm{SM}$ buffer yang sudah ditambahkan 1 tetes kloroform sebelumnya. Pen- 
campuran dilakukan pada suhu ruang (Jamalludeen et al., 2007), selanjutnya disimpan pada suhu $4{ }^{\circ} \mathrm{C}$ semalam $(18-20$ jam) untuk membiarkan partikel bakteriofag berdifusi keluar dari agar (suspensi fag) dan memberikan waktu untuk bakteri yang terinfeksi fag yang masih tersisa untuk lisis. Selanjutnya disimpan dalam suhu ruang selama 1 jam sebelum dilanjutkan dengan sentrifugasi dengan kecepatan $4000 \times$ g selama 15 menit. Supernatan yang terbentuk kemudian disaring menggunakan mikropore ukuran $0.22 \mu \mathrm{m}$, hasil yang diperoleh berupa suspensi fag.

\section{Penentuan Konsentrasi Bakteriofag}

Berdasarkan metode Adam (1959), konsentrasi lisat bakteriofag dianalisis menggunakan metode double layer agar. Sepuluh serial pengenceran dilakukan terhadap lisat fag menggunakan SM buffer. Selanjutnya dilakukan double layer agar assay terhadap setiap seri pengenceran. Setelah inkubasi selama 18-20 jam, dilakukan pengamatan pembentukan plaque pada cawan agar. Data yang diperoleh selanjutnya digunakan untuk menghitung konsentrasi fag $(\mathrm{PFU} / \mathrm{mL})$ dengan menggunakan rumus standar (Adam, 1959). Konsentrasi fag/titer menunjukan jumlah plaque forming units (PFU)/ $\mathrm{mL}$.

\section{Uji Konfirmasi Bakteriofag dalam Medium Cair}

Uji konfirmasi lisat bakteriofag spesifik Salmonella typhi dilakukan berdasarkan metode Jensen et al. (2015) dengan modifikasi. Salmonella typhi dikulturkan dalam media NB semalam (18-20 jam) pada suhu $37^{\circ} \mathrm{C}$. Kultur bakteri inang yang telah diinkubasi ditambahkan pada medium NB baru yang telah di supplementasi dengan $5 \mathrm{mM} \mathrm{CaCl}$. dan $\mathrm{MgCl}_{2}$ diinkubasi dalam inkubator shaker dengan kecepatan $200 \mathrm{rpm}$ pada suhu $37^{\circ} \mathrm{C}$ hingga mencapai $\mathrm{OD}_{600}=0.5\left(\leq 1 \times 10^{8} \mathrm{CFU} /\right.$ $\mathrm{mL}$ ). Serial pengenceran dengan SM Buffer dilakukan sampai jumlahnya mencapai $1 \mathrm{x}$ $10^{4}, 10^{6}$, dan $1 \times 10^{7} \mathrm{CFU} / \mathrm{mL}$. Kultur bakteri inang $(100 \mu \mathrm{l})$ masing-masing pengenceran ditambahkan ke dalam $60 \mathrm{ml}$ NB baru. Stok fag diencerkan menggunakan SM buffer hingga mencapai $10^{8} \mathrm{PFU} / \mathrm{mL}$. Suspensi bakteriofag ditambahkan ke dalam kultur bakteri dengan nilai Multiplicity of Infection (MOI) $10^{1}, 10^{2}$, dan $10^{4}$. Kultur selanjutnya diinkubasi menggunakan inkubator shaker pada suhu $37^{\circ} \mathrm{C}$ dengan kecepatan antara 20-30 rpm. Pengamatan nilai Optical density
$\left(\mathrm{OD}_{600}\right)$ dilakukan terhadap kultur setiap jamnya sampai terjadi lisis (terjadinya penurunan OD masing-masing bakteri inang) menggunakan spektrofotometer dengan medium standar NB. Kultur murni bakteri (hanya mengandung bakteri saja) diperlakukan sama terhadap semua tahapan perlakuan dan dijadikan kontrol.

Karakterisasi Bakteriofag Menggunakan Transmission Electron Microscopy (TEM)

Fag dimurnikan dengan PEG (polyethilen glycol) berdasarkan metode yang dijelaskan oleh Sambrook dan Russell (2018). Suspensi fag disentrifugasi pada $25000 \times \mathrm{g}$ selama 60 menit dan dicuci dua kali dalam ammonium acetate $\left(0.1 \mathrm{~mol} \mathrm{~L}^{-1}, \mathrm{pH} 7\right)$. Sedimen diendapkan pada grid tembaga dengan Formvar film yang dilapisi karbon, diwarnai dengan $2 \%(\mathrm{w} / \mathrm{v})$ uranil asetat $(\mathrm{pH}$ 4.2) dan diuji dalam Mikroskop Elektron Philip EM 300 yang dioperasikan pada $60 \mathrm{kV}$. Pembesaran dikontrol menggunakan katalase kristal (Polaron Electron Opticals, LTD, London, UK).

\section{HASIL DAN PEMBAHASAN}

\section{Penentuan Fase Medium Log (Midlog) Salmonella typhi}

Fase medium log kultur Salmonella typhi pada medium Nutrien broth (NB) yang digunakan pada penelitian ini dicapai dengan nilai absorbansi OD600 $\leq 0.5$ pada jam ke-4 waktu pengamatan dengan jumlah sel $\pm 1.56 \times 10^{8} \mathrm{CFU} / \mathrm{mL}$ seperti yang ditunjukkan pada Gambar 2. Jumlah atau konsentrasi bakteri inang yang digunakan akan mempengaruhi efisiensi keberhasilan isolasi bakteriofag. Semakin banyak jumlah bakteri yang ditambahkan maka semakin cepat adsorpsi fag terjadi (Wang, 2006; Moldovan et al., 2007; Marcó et al., 2010; Zemb et al. 2013; Storms dan Sauvageau, 2015; Malik et al., 2017).

\section{Pengkayaaan dan Isolasi Bakteriofag \\ Bakteriofag spesifik Salmonella typhi dapat lebih mudah diisolasi dari sumber alami. Semakin tinggi keberadaan Salmo- nella typhi maka isolasi bakteriofag semakin mudah dilaksanakan. Salmonella typhi yang mempunyai habitat alami pada saluran pencernaan unggas dapat mengkontaminasi}




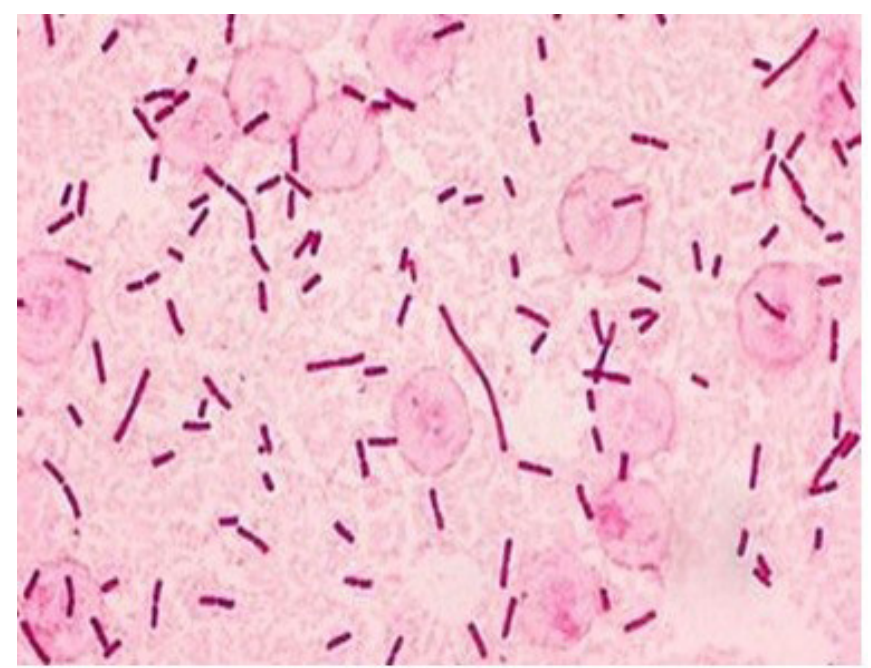

Gambar 1. Salmonella enterica serovar Thypi (S. typhi) (Sumber : Microbe-canvas, 2018)

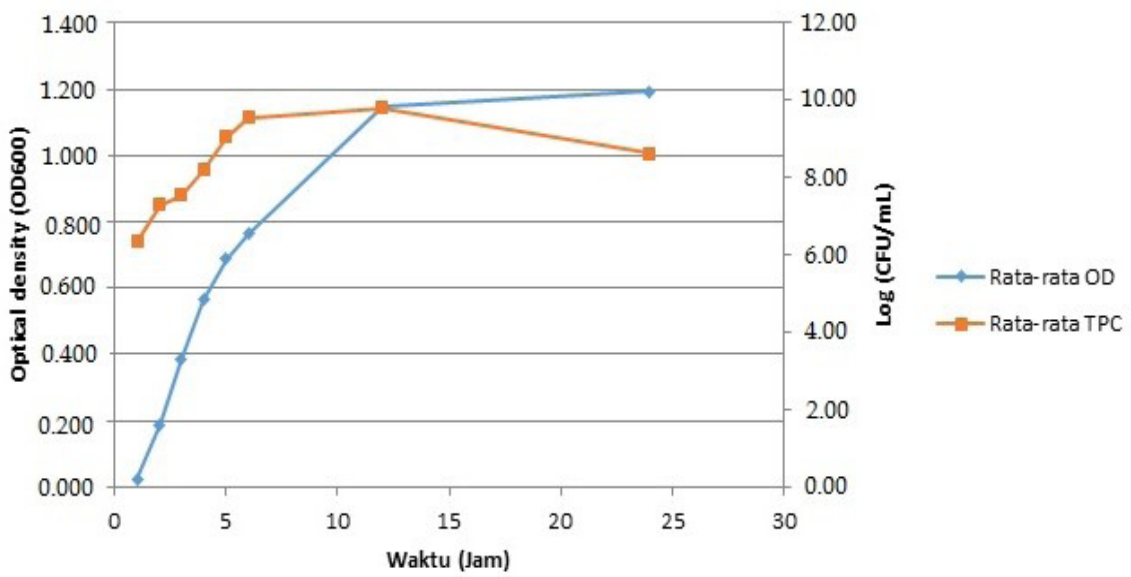

Gambar 2. Kurva Pertumbuhan Salmonella typhi selama 24 jam pada suhu $37^{\circ} \mathrm{C}$

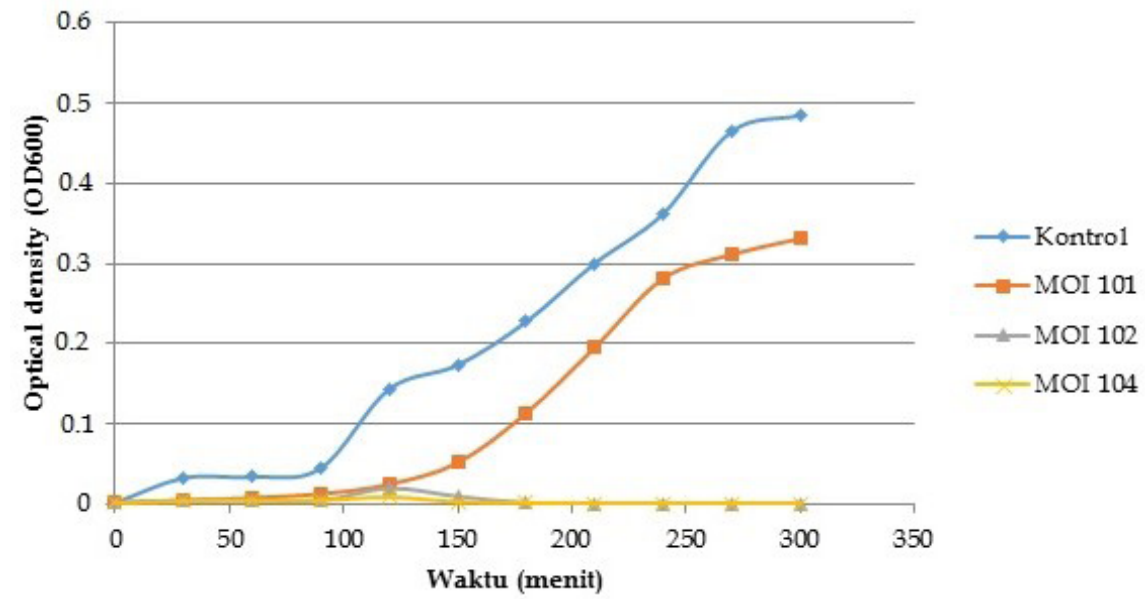

Gambar 3. Morfologi plaque isolat fag KAS 
karkas unggas khususnya ayam pada semua proses tahapan penanganan yang terjadi di rumah potong hewan. Salmonella typhi yang menempel pada kulit ayam khususnya tidak dapat dihilangkan dengan proses pencucian sehingga keberadaan Salmonella typhi menjadi lebih tinggi pada kulit dibandingkan pada daging ayam (Sans dan Combris, 2015). Keberadaan berbagai nutrisi yang diperlukan serta tingkat aw yang tinggi menjaga kestabilan jumlah Salmonella typhi pada kulit ayam sehingga tidak dibutuhkan medium yang diperkaya atau penambahan kultur Salmonella typhi murni pada saat proses awal isolasi. Inkubasi filtrat sampel semalaman pada suhu $4{ }^{\circ} \mathrm{C}$ efektif membuat fag keluar dari sampel dan terlarut di dalam larutan SM buffer. Leher ayam berkulit adalah bagian tubuh dari ayam yang paling rentan terhadap kontaminasi Salmonella typhi dibandingkan bagian tubuh yang lainnya (Wu et al., 2014).

Isolasi bakteriofag menggunakan metode plaque assay (Adam, 1959) dengan teknik double layer agar telah berhasil mengisolasi fag spesifik Salmonella typhi yang berasal dari kulit ayam. Visualisasi keberadaan bakteriofag ditunjukan dengan terbentuknya plaque pada bacterial lawn (koloni bakteri inang pada agar cawan). Plaque adalah sel bakteri yang dilisiskan virus. Satu plaque mengindikasikan satu sel bakteri lisis.

Keberhasilan pembentukan plaque dipengaruhi oleh ion divalent seperti $\mathrm{CaCl}_{2}$ atau $\mathrm{MgCl}_{2}$ (Paunikar et al., 2012), densitas agar, konsentrasi bakteri inang-fag serta aplikasi yang digunakan (Heyse et al., 2015). Keberadaan $\mathrm{CaCl}_{2}$ atau $\mathrm{MgCl}_{2}$ serta densitas agar yang tepat berpengaruh pada peningkatan interaksi antara fag dengan sel inang pada saat adsorpsi (McNerney et al., 2004), mempermudah difusi fag terhadap bakteri inang (Abedon et al., 2009) serta mengoptimalkan waktu lisis fag.

Plaque dari isolat fag yang berhasil diisolasi setelah 18-20 jam inkubasi pada suhu 37 ${ }^{\circ} \mathrm{C}$ diberi nama KAS yang merupakan singkatan dari kulit ayam (sebagai sumber fag) dan Salmonella typhi (sebagai bakteri inang), memiliki karakteristik bening (clear plaque) dengan batas antara zona lisis dan bacterial lawn yang terlihat jelas pada Gambar 3. Clear plaque yang terbentuk menandakan bahwa isolat fag KAS bersifat litik dan virulen terhadap sel bakteri inang (Salmonella typhi).

Ukuran plaque (daerah permukaan plaque) yang teramati pada bacterial lawn dari isolat fag KAS pada Gambar 3 memiliki diameter antara $0.3-1.1 \mathrm{~cm}$. Gallet et al. (2011) menyatakan bahwa ukuran plaque yang teramati pada bacterial lawn, dipengaruhi oleh morfologi virion fag dan waktu lisis (lisis time/laten periode=lamanya waktu produksi fag dalam fase intraseluler sebelum sel lisis). Morfologi virion fag yang berbeda akan memiliki ukuran plaque yang berbeda juga, sedangkan ukuran plaque akan maksimal jika waktu lisisnya optimal. waktu lisis optimum dicapai dengan lama waktu sedang (intermediate), tidak terlalu lama dan tidak terlalu pendek.

\section{Konsentrasi Isolat Fag KAS}

Plaque yang terbentuk kemudian dimurnikan dengan teknik single plaque isolation dan ditentukan konsentrasinya akhirnya menggunakan perhitungan rumus standar (Adam, 1959). Konsentrasi akhir dari lisat fag KAS adalah $1.1 \times 10^{9}$. Lisat fag murni selanjutnya dilarutkan dalam SM buffer dan disimpan pada suhu $4{ }^{\circ} \mathrm{C}$ untuk selanjutnya dilakukan pengujian, sedangkan lisat stok yang akan disimpan dalam waktu lama (< 1 tahun) disuplementasi dengan 50\% [v/v] gliserol steril dan ditempatkan pada Cryotube disimpan pada suhu $-80^{\circ} \mathrm{C}$.

\section{Uji Konfirmasi Bakteriofag dalam Medium Cair}

Proses lisis pada bakteri inang dapat diuji dengan mengamati perubahan jumlah (densitas) pada bakteri yang diinfeksi dibandingkan dengan densitas bakteri yang tidak mengalami lisis (kontrol). Perubahan densitas bakteri dilakukan dengan melakukan pengukuran nilai absorbansi (Optical density) menggunakan panjang gelombang $600 \mathrm{~nm}$ $\left(\mathrm{OD}_{600}\right)$ dengan menggunakan NB sebagai medium pertumbuhan. Pengukuran $\mathrm{OD}_{600}$ dilakukan terhadap kultur bakteri Salmonella typhi yang diinfeksi dengan bakteriofag KAS. Pengukuran $\mathrm{OD}_{600}$ dilakukan dengan interval waktu 30 menit sampai didapatkan penurunan nilai $\mathrm{OD}_{600}$ yang signifikan dari masing-masing perlakuan. Pengurangan nilai $\mathrm{OD}_{600}$ merupakan akibat dari proses lisis bakteri inang yang akan mengurangi jumlah total bakteri yang digunakan pada awal perlakuan. Hasil pengujian terhadap nilai $\mathrm{OD}_{600}$ masingmasing perlakuan dibandingkan dengan nilai $\mathrm{OD}_{600}$ kontrol (kultur bakteri inang yang tidak diinfeksi bakteriofag). 
Salmonella typhi yang diinfeksi oleh bakteriofag KAS (A) dengan perlakuan nilai MOI $10^{2}$ dan $10^{4}$ mengalami kenaikan nilai $\mathrm{OD}_{600}$ dari awal waktu pengamatan yaitu menit ke-0 $\left(\mathrm{OD}_{600}=0.001\right)$ menjadi masing-masing 0.019 dan 0.008 pada menit ke-120 dan menurun nilainya pada menit ke-150 masing-masing menjadi 0.009 dan 0.002 serta terus menurun nilainya di waktu pengamatan setelahnya dan masing-masing mengalami kematian inang total pada waktu pengamatan menit ke-210 sampai akhir waktu pengamatan yaitu menit ke 300. Kurva lisis bakteri Salmonella typhi dengan penambahan bakteriofag KAS dapat dilihat pada Gambar 4.

Pengukuran densitas sel inang yang dinyatakan dalam nilai Optical density $\left(\mathrm{OD}_{600}\right)$ merupakan metode yang dilakukan untuk melakukan pengukuran terhadap sel hidup yang ada dalam medium cair. Pengukuran Optical density $\left(\mathrm{OD}_{600}\right)$ pada kontrol (tidak ditambahkan fag) menghasilkan nilai $\mathrm{OD}_{600}$ yang terus meningkat selama waktu pengamatan. Hal ini menunjukan bahwa sel inang berada pada fase pertumbuhan secara normal. Peningkatan nilai $\mathrm{OD}_{600}$ selama waktu pengamatan terjadi juga pada perlakuan MOI $10^{1}$, akan tetapi nilai $\mathrm{OD}_{600}$ masih berada di bawah kontrol. Hal ini menunjukan bahwa penambahan isolat fag KAS berpengaruh menghambat pertumbuhan sel inang meskipun belum mampu melisiskan sel inang.

Penurunan nilai absorbansi $\left(\mathrm{OD}_{600}\right)$ terhadap densitas bakteri inang yang ditambahkan fag KAS dengan MOI $10^{2}$ dan $10^{4}$ menunjukan terjadinya lisis sel inang bakteri

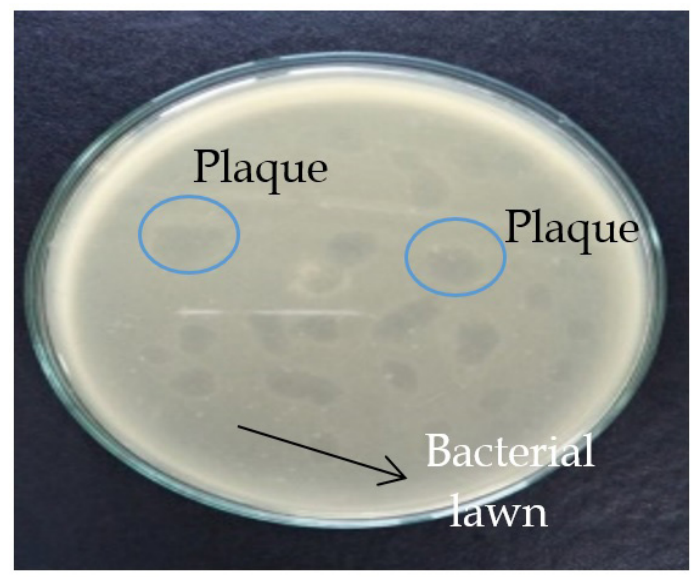

Gambar 4. Kurva lisis bakteri Salmonella typhi dengan penambahan bakteriofag KAS akibat infeksi fag KAS yang dimulai pada menit ke-150 waktu pengamatan. Kematian total inang yang terjadi pada perlakuan MOI $10^{2}$ dan $10^{4}$ di menit ke-180 sampai dengan akhir waktu pengamatan merupakan akibat dari jumlah fag yang ada pada medium sudah sangat tinggi sementara densitas sel inang terus menurun karena lisis sampai akhirnya tidak ada lagi sel inang yang hidup yang dapat diinfeksi fag.

\section{Karakterisasi Morfologi Isolat Fag KAS}

Hasil TEM terhadap isolat Fag KAS dengan perbesaran 60000 kali menampilkan karakteristik kepala yang diduga berbentuk simetri kubik dengan ekor yang sangat pendek tidak jelas terlihat di Gambar 5.

Berdasarkan hasil penelitian Rattanachaikunsopon dan Phum (2009), Salmonella typhi memiliki asam nukleat berupa linear double stranded DNA (dsDNA,L). Berdasarkan klasifikasi terbaru yang dikemukakan oleh Ackermann (2007) mengelompokan virus berekor dengan asam nukelat (dsDNA,L) dengan ke dalam tiga famili yaitu Myoviridae (ekor kontraktil), Siphoviridae (ekor panjang non kontraktil), dan Podoviridae (ekor pendek).

Gambaran morfologi isolat fag KAS dengan dilengkapi informasi klasifikasi Ackermann (2007) mengelompokan fag KAS sementara ke dalam famili Podoviridae, karena penempatan takson pada klasifikasi virus baru tepat setelah sekuen DNA secara utuh dari fag diketahui.

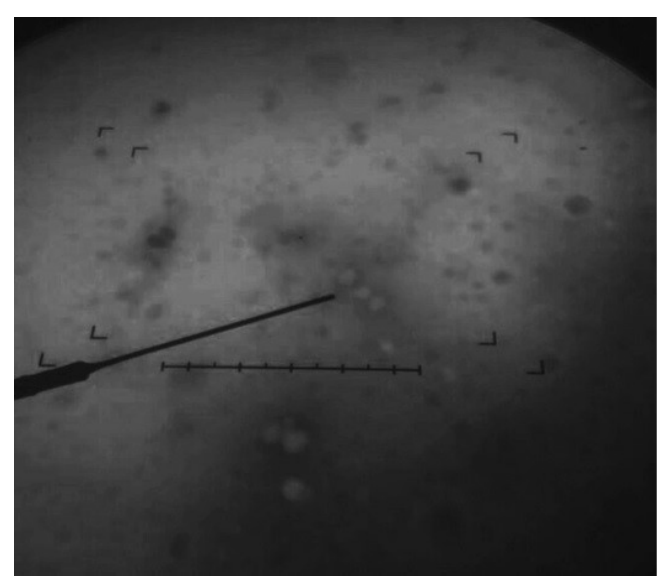

Gambar 5. Hasil pengamatan menggunakan isolat fag KAS, perbesaran 60000x 
Jurnal Teknologi Pertanian Vol. 19 No. 2 [Agustus 2018] 107-116

Isolasi dan Karakterisasi Bakteriofag Spesifik Salmonella typhi [Hardanti dkk]

\section{SIMPULAN}

Isolat fag KAS yang berhasil diisolasi dari kulit ayam merupakan fag litik yang virulen. Berdasarkan hasil uji konfirmasi pada medium cair, isolat fag KAS memiliki potensi untuk dapat digunakan sebagai biokontrol bakteri penyebab demam tifoid. Isolat fag KAS termasuk ke dalam famili Podoviridae.

\section{DAFTAR PUSTAKA}

Abedon, S, T, Yin, J. 2009. Bacteriophage plaques: theory and analysis. Methods. Mol. Biol. 501(1):161-174

Ackermann, H, W. 2007. 5500 Phages examined in the electron microscope. Archives of Virology. 152(2):227-243

Adam, MH. 1959. Bacteriophage. Interscience Publishers, Inc. New York

Alba, S, Bakker, M, I, Hatta, M, Scheelbeek, P, F, Dwiyanti, R, Usman, R, Andi, S, M, Tandirogang, N, Amir, M, Pastoor, R, Beers, S, V, Smits, H, L, Yasir, Y. 2016 Risk factors of typhoid infection in the indonesian archipelago. PloS one. 11(6)

Atterbury, R, J, Connerton, P, L, Dodd, C, E, Rees, C, E, Connerton, I, F. 2003. Isolation and characterization of Campylobacter bacteriophages from retail poultry. Appl. Environ. Microbiol. 69(8):4511-4518

Buckle, G, C, Walker, C, L, F, Black, R, E. 2012. Typhoid fever and parjensenatyphoid fever: Systematic review to estimate global morbidity and mortality for 2010. J. Glob. Health. 2(1)

Casjens, S, R. 2008. Diversity among the tailed-bacteriophages that infect the Enterobacteriaceae. Res Microbiol. 159(5):340-348

Cheng, J, H, Yang, H, Liu, M, L, Su, W, Feng, P, M, Ding, H, Chen, W, Lin, H. 2018. Prediction of bacteriophage proteins located in the host cell using hybrid features. Chemometrics and Intelligent Laboratory Systems. 180:64-69

Crump, J, A, Luby, S, P, Mintz, E, D. 2004. The global burden of typhoid fever. Bull. World. Health. Organ. 82:346-353

Connerton, PL, Connerton, IF. 2005. 'Microbial treatments to reduce pathogens in poultry meat'. Dalam GC Mead (ed.). Food Safety Control in the Poultry Industry. Woodhead Publishing Ltd., Cambridge

Donnison AM, Ross, CM. 2014. 'Thermotolerant Campylobacter'. Dalam A Søren. Microbiological Safety of Meat volume 2. Elsevier, UK

Gallet, R, Kannoly, S, Wang, I, N. 2011. Effects of bacteriophage traits on plaque formation. BMC microbiology. 11(1):181

Harada, L, K, Silva, E, C, Campos, W, F, Del Fiol, F, S, Vila, M, Dabrowska, K, Krylov, V, N, Balcão, V, M. 2018. Biotechnological applications of bacteriophages: State of the art. Microbiological Research. 212:38-58

Hatta, M, Ratnawati. 2008. Enteric fever in endemic areas of indonesia: an increasing problem of resistance. J. Infect. Dev. Ctries. 2(4):279-282

Heyse, S, Hanna, L, F, Woolston, J, Sulakvelidze, A, Charbonneau, D. 2015. Bacteriophage cocktail for biocontrol of Salmonella in dried pet food. J Food. Prot. 78(1):97-103

Jamalludeen, N, Johnson, R, P, Friendship, R, Kropinski, A, M, Lingohr, E, J, Gyles, C, L. 2007. Isolation and characterization of nine bacteriophages that lyse O149 enterotoxigenic Escherichia coli. Veterinary Microbiology. 124(1):47-57

Jensen, K, C, Hair, B, B, Wienclaw, T, M, Murdock, M, H, Hatch, J, B, Trent, A, T, White, T, D, Haskell, K, J, Berges, B, K. 2015. Isolation and host range of bacteriophage with lytic activity against methicillin-resistant Staphylococcus aureus and potential use as a fomite decontaminant. PloS one. 10(7)

Kang, H, W, Kim, J, W, Jung, T, S, Woo, G, J. 2013. Wksl3, a new biocontrol agent for Salmonella enterica serovars Enteritidis and Typhimurium in foods: characterization, application, sequence analysis, and oral acute toxicity study. Applied and Environmental Microbiology. 79(6):1956-1968

Kittler, S, Wittmann, J, Mengden, R, A, L, P, Klein, G, Rohde, C, Lehnherr, H. 2017. The use of bacteriophages as OneHealth approach to reduce multidrugresistant bacteria. Sustainable Chemistry and Pharmacy. 5:80-83

Loessner, M,J, Busse, M. 1990. Bacteriophage typing of Listeria species. Applied and 
Environmental Microbiology. 56(6):19121918

Malik, D, J, Sokolov, I, J, Vinner, G, K, Mancuso, F, Cinquerrui, S, Vladisavljevic, G, T, Clokie, M, R, J, Garton, N, J, Stapley, A, G, F, Kirpichnikova, A. 2017. Formulation, stabilisation and encapsulation of bacteriophage for phage therapy. Advances in Colloid and Interface Science. 249:100-133

Marcó, M, B, Reinheimer, J, A, Quiberoni, A. 2010. Phage adsorption to Lactobacillus plantarum: Influence of physiological and environmental factors. International Journal of Food Microbiology. 138(3):270-275

McNerney, R, Kambashi, B, S, Kinkese, J, Tembwe, R, Godfrey-Faussett, P. 2004. Development of a bacteriophage phage replication assay for diagnosis of pulmonary tuberculosis. Journal of Clinical Microbiology. 42(5):2115-2120

Microbe-canvas. 2018. Salmonella typhi. Dilihat 19 Maret 2018. <http://microbecanvas.com/Bacteria.php? $p=1268>$

Mogasale, V, Maskery, B, Ochiai, R, L, Lee, J, S, Mogasale, V, V, Ramani, E, Kim, Y, E, Park, J, K, Wierzba, T, F. 2014. Burden of typhoid fever in low-income and middle-income countries: a systematic, literature-based update with risk-factor adjustment. The Lancet Global Health. 2(10):e570-e580

Moldovan, R, Chapman-Mcquiston, E, $\mathrm{Wu}, \mathrm{X}, \mathrm{L}$. 2007. Biophysical Journal. 93(1):303-315

Ochiai, R, L, Acosta, C, J, Danovaro-Holliday, M, C, Baiqing, D, Bhattacharya, S, K, Agtini, M, D, Bhutta, Z, A, Chanh, D, G, Ali, M, Shin, S, Page, A, L, Albert, M, J, Farrar, J, Abu-Elyazeed, R, Pang, T, Galindo, , C, M, Von Seidlein, L, Clemens, J, D. 2008. A study of typhoid fever in five asian countries: disease burden and implications for controls. Bulletin of the World Health Organization. 86(4):260-268

Paunikar, W, N, Sanmukh, S, G, Ghosh, T, K. 2012. Effect of metal ions and chemical solvents on the adsorption of salmonella phage on salmonella choleraesuis subspecies Indica. International Journal of Pharma and Bio Sciences. 3:181-190

Pedulla, M, L, Ford, M, E, Houtz, J, M, Karthikeyan, T, Wadsworth, C, Lewis, J, A, Jacobs-Sera, D, Falbo, J, Gross, J,
Pannunzio, N, R, Brucker, W, Kumar V, Kandasamy, J, Keenan, L, Bardarov, S, Kriakov J, Lawrence, J, G, Jacobs, W, R, Jr, Hendrix, R, W, Hatfull, G, F. 2003. Origins of highly mosaic mycobacteriophage genomes. Cell. 113(2):171-182 Rao, S, P, N. 2006 Bachteriopage. Dilihat tanggal 24 September 2016. <http://www.microrao.com/micronotes/bacteriophage.pdf>

Rattanachaikunsopon, P, Phumkhachorn, P. 2009. Prophylactic effect of Andrographis paniculata extracts against Streptococcus agalactiae infection in Nile tilapia (Oreochromis niloticus). Journal of Bioscience and Bioengineering. 107(5):579-582

Sambrook, J, Russell, D. W. 2018. Molecular cloning: a laboratory manual. Dilihat 12 Juli 2018. < https://www.cshlpress.com/pdf/sample/2013/MC4/ MC4FM.pdf>

Sans, P, Combris, P. 2015. World meat consumption patterns: an overview of the last fifty years (1961-2011). Meat Science. 109:106-111

Santos, S, B, Costa, A, R, Carvalho, C, Nóbrega, F, L, Azeredo, J. 2018. Exploiting Bacteriophage Proteomes: The Hidden Biotechnological Potential. Trends in Biotechnology. 36(9):966-984

Shende, R, K, Hirpurkar, S, D, Sannat, C, Rawat, N, Pandey, V. 2017. Isolation and characterization of bacteriophages with lytic activity against common bacterial pathogens. Veterinary World. 10(8):973-978

Storms, Z, J, Sauvageau, D. 2015. Modeling tailed bacteriophage adsorption: Insight into mechanisms. Virology. 485:355-362

Strydom, A, Witthuhn, C, R. 2015. Listeria monocytogenes: a target for bacteriophage biocontrol. Comprehensive Reviews in Food Science and Food Safety. 14(6):694-704

Susianto, G, Farid, M, M, Dhany, N, R, Addy, H, S. 2014. Host range for bacteriophages that infect bacterial blight pathogen on soybean. Procedia Environmental Sciences. 20:760-766

Wang, N. 2006. Lysis timing and bacteriophage fitness. Genetics. 172(1):17-26

Wu, D, Alali, W, Q, Harrison, M, A, Hofacre, C, L. 2014. Prevalence of Salmonella in neck skin and bone of chickens. Journal of Food Protection. 77(7):1193-1197 
Jurnal Teknologi Pertanian Vol. 19 No. 2 [Agustus 2018] 107-116

Isolasi dan Karakterisasi Bakteriofag Spesifik Salmonella typhi [Hardanti dkk]

Yang, H, Liang, L, Lin, S, Jia, S. 2010. Isolation and characterization of a virulent bacteriophage AB1 of Acinetobacter baumannii. BMC Microbiology. 10(1):131
Zemb, O, Manefield, M, Thomas, F, Jacquet, S. 2013. Phage adsorption to bacteria in the light of the electrostatics: A case study using E. coli, T2 and flow cytometry. Journal of Virological Methods. 189(2):283-289 